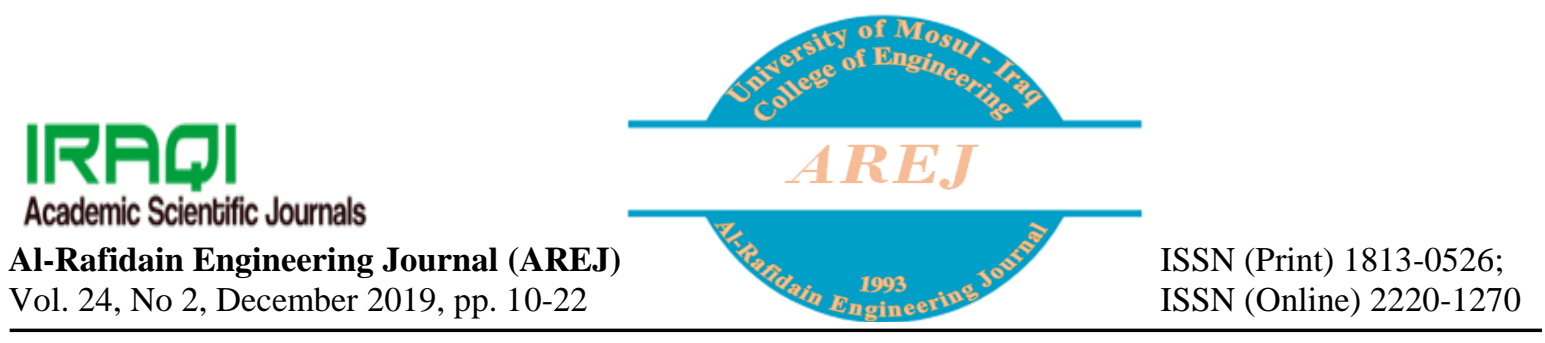

\title{
Investigation of Local Scour Around Group Bridge Pier with Different Shapes
}

\author{
Tahseen A. GELMIRAN ${ }^{*}$ Khalil I. Othman** Mustafa GUNAL ${ }^{* * * *}$ \\ tahssenali1967@uomosul.edu.iq kalil_othman@uomosul.edu.iq gunal@gantep.edu.tr \\ *, ** Dams and Water Research Center, Mosul University, Mosul, Iraq. \\ *** Civil Engineering, Gaziantep University, Gaziantep, Turkey.
}

Received: 17- 4 -2019

Accepted: 30- 12 -2019

\section{ABSTRACT}

In this study, the establish on laboratory experiments for computing the depth of local scour $\left(\mathrm{d}_{\mathrm{s}}\right)$ around group bridge pier. For this purpose, fifteen models of bridge piers were constructed and tested, divided into five groups, of each group containing three bridge piers with the same specifications. The diameter of upstream bridge piers $\left(\mathrm{D}_{1}\right)$ was varied to $2,4,6,8$, and $10 \mathrm{~cm}$, and diameter of downstream bridge piers $\left(\mathrm{D}_{2}\right) 10 \mathrm{~cm}$ for all. The spacing $(\mathrm{S})$ between the bridge piers was varied three times 20,30 , and $50 \mathrm{~cm}$ for all groups. Considering the effectiveness study of upstream flow conditions, the size of diameters of bridge piers, the spacing between bridge piers and medium size of bed material on the maximum scour depth and scour pattern around bridge piers. The study was conductedby employing a physical hydraulic model for bridge piers operated below subcritical flow, clear-water condition and exploitation uniform cohesionless sand as bed material. The experimental results showed the scour depth $\left(\mathrm{d}_{\mathrm{s}}\right)$ increasing whenever increasing the upstream diameter $\left(D_{1}\right)$ of bridge pier and decreasing whenever decreasing the spacing $(\mathrm{S})$ between bridge piers. The dimensional analysis techniques and statistical program were used for locating a new empirical formula with the facilitate of the experimental information; this formula is for calculating the maximum scour depth at bridge piers.

\section{Keywords:}

Group bridge pier, local scour Different shapes of piers, the Different spacing between piers, Different upstream pier diameters.

https://rengj.mosuljournals.com

Email: alrafidain_engjournal1@umosul.edu.iq 


\section{List of symbols}

$$
\begin{array}{ll}
\mathrm{d}_{\mathrm{s}} & \text { Maximum sour depth }(\mathrm{m}) \\
\mathrm{y} & \text { Flow depth }(\mathrm{m}) \\
\mathrm{V} & \text { Mean approach flow velocity }(\mathrm{m} / \mathrm{s}) \\
\mathrm{V}_{\mathrm{c}} & \text { Critical velocity }(\mathrm{m} / \mathrm{s}) \\
\rho & \text { Density of water }\left(\mathrm{kg} / \mathrm{m}^{3}\right) \\
\mathrm{g} & \text { Gravitation acceleration }\left(\mathrm{m} / \mathrm{s}^{2}\right) \\
\mathrm{S} & \text { Spacing between the bridge piers }(\mathrm{m}) \\
\mathrm{Fr} & \text { Froude number } \\
\mathrm{d}_{16} & \text { Grain size for which } 16 \% \text { by the weight }
\end{array}
$$

of the sediment infiner ( $\mathrm{mm})$

$\mathrm{d}_{50} \quad$ Median particle grain size $(\mathrm{mm})$

$\mathrm{d}_{84} \quad$ Grain size for which $84 \%$ by the weight

of the sediment infiner (mm)

$\mu \quad$ Dynamic viscosity of water ( $\mathrm{kg} / \mathrm{m} . \mathrm{s})$

B Width of flume (m)

$\mathrm{D}_{1} \quad$ Upstream diameter of the bridge

pier (m)

$\mathrm{D}_{2} \quad$ Downstream diameter of the bridge pier (m)

$$
\mathrm{L} \quad \text { Length of the bridge pier (m) }
$$

\section{INTRODUCTION}

The term of scour is used to designate erosion by flowing water, resulting in undermining foundation or bank, in lowering a stream bed below its natural or average level [1]. Scour is a physical phenomenon caused by the erosive behavior of flowing water on the bed and banks of canals [2].The scour activity around piers can be the primary cause of bridge failure, correct estimation of the depth of scour below the streambed is crucial because it influences the depth of foundation [3]. It is vital to study the detrimental effects the river flow can have on the stability of piers that support a bridge in the river [4]. Scour has long been decided that the basic mechanism causing topical scour at bridge piers the down flow at the upstream face of the bridge piers and pointing of vortices at the foundation $[5,6]$. These three phenomena are driven by hydrodynamic processes of descending spatial scale and increasing modeling [7]. The scour specified two main classifications of topical scour at bridge piers based on the procedure of sediment transport by the relative stream, namely clear water scour and live bed scour; itoccurs when the scour hole is continually replenished with sediment by approach flow [8]. Factors affecting the magnitude of the local scour depth at bridge piers as given are: flow depth,velocityof the flow, bridge pier size, gravitational acceleration, bridge pier long if skewed to the main flow direction, size and gradation of the bed material, angle of attack of the approach flow to the bridge pire, shape of the bridge pier and bed configuration $[9,10]$. The shape and spacing between the bridge piers have a very importantimpact on the maximum local scour depth. Thus, the different of the shapes and spacing between the bridge piers should be investigated experimentally and numerically to search out a dependable efficiency before field application, particularly under live bed scour conditions. Decrease the depth of scouring around the bridge piers has been studied by many types of research experimentally and numerically. Nandana and et al.[11], in this study, was concluded the orientation group bridge piers of scour depth the $30^{\circ}$ orientation leading to a minimum scour depth is taken into account the best direction and adopted in experiments on partial group bridge pier of $60^{\circ}$ orientation resulted in maximum scour depth.Debnath and Chaudhuri [12],in this study the maximum of the scour depth for round-nosed bridge piers were a generally lower while, the values of scour depths were higher for the square and rectangular bridge piers compared to the circular bridge pier for comparable bed material characteristics. Shatirah and et al. [13], in this investigation the scour time expansion was greater for higher flow depth and flow discharge at semi-integral bridges, and therefore the balance scour depth increased with path of the flow depth around group bridge piers at semi-integral. The scour depth different with distance and therefore the scour expansion of the upstream was higher compared to the downstream before it amount to the equilibrium state. Adnan and et al. [14], in this study behave the result of the change within the position of bridge piers of the scour decrease with reference to flow direction and applied three bridge piers, circular $10 \mathrm{~cm}$ diameter, upstream facing round-nosed (10-4) $\mathrm{cm}$ diameters and downstream facing round-nosed (4-10) $\mathrm{cm}$ diameters of bridge piers were tested of the under live-bed sand material with the discharge $58 \mathrm{l} / \mathrm{s}$, for period of 180 minutes.Equilibrium scour is said to occur when the scour depth does not change appreciably with time. Equilibrium can also be defined as the asymptotic state of scouringcompass as the scouring rate becomes very small. An equilibrium between the erosive capability of the flow and the resistance to motion of the bed materials is progressively obtain through erosion of the flow 
boundary [15]. In this study, the depth of scouring around the bridge piers was measured for 360 minutes, but equilibrium depth scours achieved after less than 180 minutes for all experiments.

\section{EXPERIMENTAL PROGRAM}

The experimental work of this study was disbursed atHydraulicLaboratory of Civil Engineering Department of Gaziantep University.The work was planned and disbursed to produce elaborated data on the local scour around group bridge piers with entirely different shape and spacing. The experimental work was carried out in a flume having a working length of $12 \mathrm{~m}$ with a cross section $0.8 \mathrm{~m}$ width and $0.9 \mathrm{~m}$ deep. The side walls were of toughened glass with some perspex panels jointed. The flume bed was supported by steel under the frame to permit accurate alignment. The test section of the sand bed was made with a ramp located at the beginning and the end of this section $4 \mathrm{~m}$ long and $0.2 \mathrm{~m}$ depth, Fig.1.

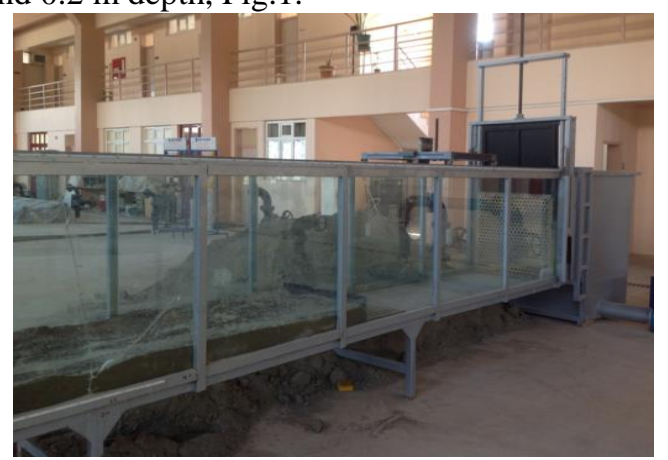

Fig. 1 Side view of the flume.

The equipment could be a closed system water recirculating flume with the movable bed. Water is equippedwith the reservoir below the ground by a pump that is located on made up steel base plate. The pump lies beside the flume at upstream. Magnetic flow meter to measure discharge were put in within the pipe before the inlet of the channel as illustrated in Fig. 2.

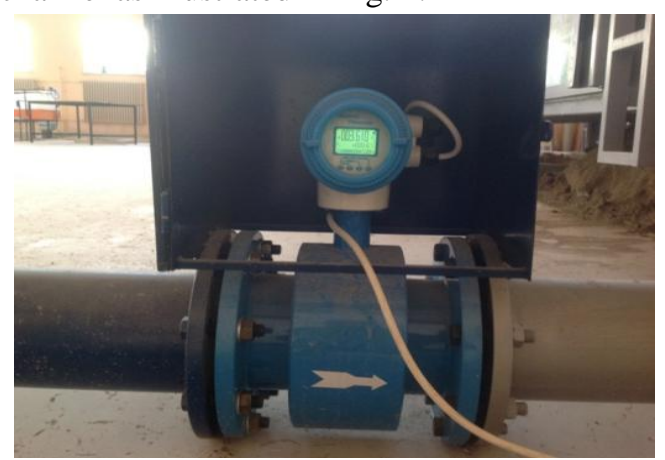

Fig. 2 Magnetic flow meter.

The models of bridge were made from solid wood, five different group of bridge piers are use in the scouring tests, upstream diameters $\left(\mathrm{D}_{1}\right)$ are $2,4,6,8$, and $10 \mathrm{~cm}$ respectively, downstream diameter $\left(D_{2}\right) 10 \mathrm{~cm}$ for all piers, $50 \mathrm{~cm}$ heights and $20 \mathrm{~cm}$ length, Fig.3, shows photographs and dimensions of tested the group bridge piers.

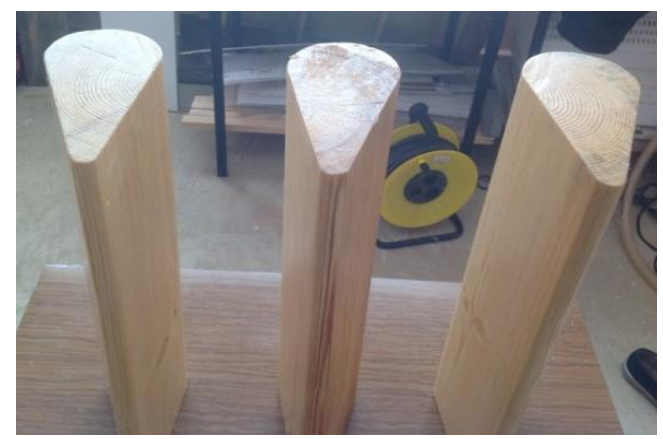

Group $1\left(2-10, D_{1}=2 \mathrm{~cm}, D_{2}=10 \mathrm{~cm}\right)$

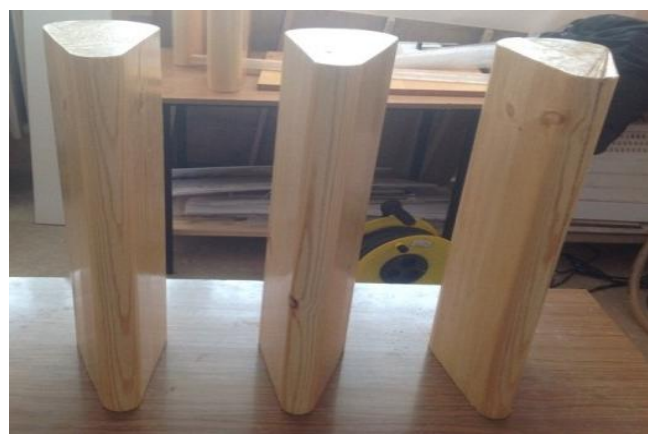

Group $2\left(4-10, D_{1}=4 \mathrm{~cm}, D_{2}=10 \mathrm{~cm}\right)$

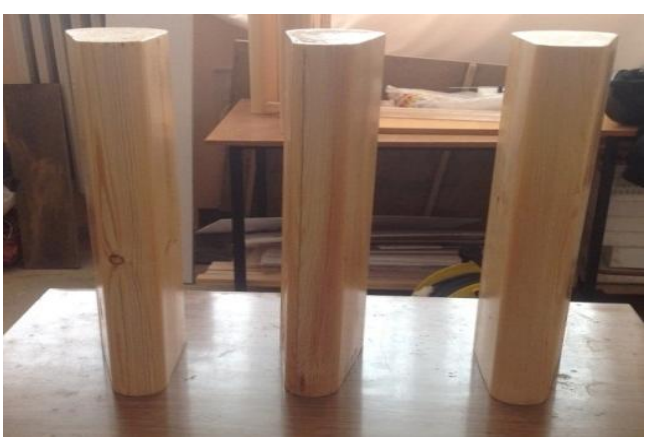

Group $3\left(6-10, D_{1}=6 \mathrm{~cm}, D_{2}=10 \mathrm{~cm}\right)$

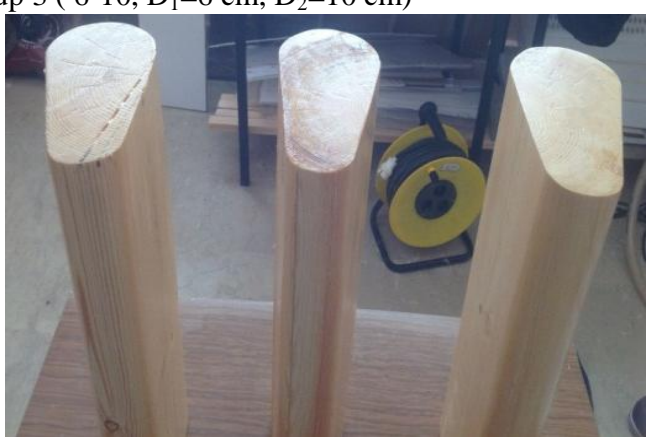

Group $4\left(8-10, D_{1}=8 \mathrm{~cm}, D_{2}=10 \mathrm{~cm}\right)$ 


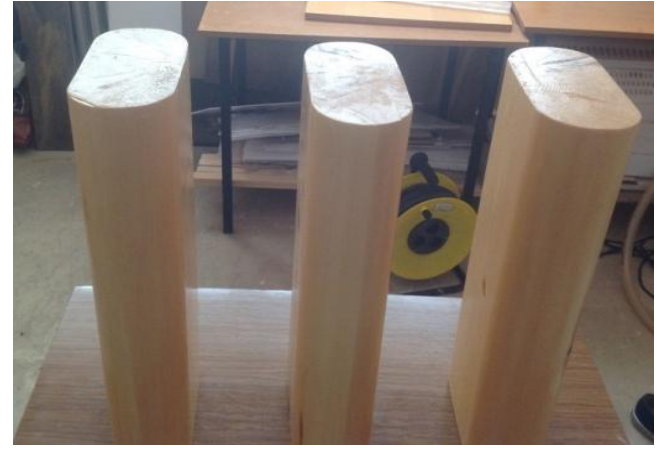

Group $5\left(10-10, D_{1}=10 \mathrm{~cm}, \mathrm{D}_{2}=10 \mathrm{~cm}\right)$

Fig.3 Photographs and dimensions of tested group bridge piers.

In each case the group bridge piers were placed on the center line of the channl and at a particular longitudinal section, keeping the coordination's of group bridge piers center line constant for all the conducted experiments. Use three spacing between the bridge piers $20 \mathrm{~cm}, 30 \mathrm{~cm}$ and $50 \mathrm{~cm}$, and use three discharges $57 \mathrm{l} / \mathrm{sec}, 48 \mathrm{l} / \mathrm{sec}$, and 38 1/sec, Table 1.

Table 1:Summary of test for group piers.

\begin{tabular}{c|c|c|c|c}
\hline \multicolumn{4}{c}{ Mode No. Span Lengths Discharge } \\
& cm & 57 & 48 & 38 \\
\multirow{3}{*}{$2-10$} & 50 & 57 & 48 & 38 \\
& 30 & 57 & 48 & 38 \\
\hline \multirow{3}{*}{$4-10$} & 20 & 57 & 48 & 38 \\
& 50 & 57 & 48 & 38 \\
& 30 & 57 & 48 & 38 \\
\hline \multirow{3}{*}{$6-10$} & 20 & 57 & 48 & 38 \\
& 50 & 57 & 48 & 38 \\
& 30 & 57 & 48 & 38 \\
\hline \multirow{3}{*}{$8-10$} & 20 & 57 & 48 & 38 \\
& 50 & 57 & 48 & 38 \\
& 30 & 57 & 48 & 38 \\
\hline & 20 & 57 & 48 & 38 \\
& 50 & 57 & 48 & 38 \\
& 30 & 57 & 48 & 38 \\
\hline
\end{tabular}

\section{SAND BED}

A mechanical sieve analysis test was meted out to characterize the sand bed material used for study Fig. 4. The test results showed that the bed material depend of cohesionless sand with a median particle size $\left(\mathrm{d}_{50}\right)$ equal to $1.6 \mathrm{~mm}$ and a specific gravity of 2.65 . The geometric standard deviation of the sand size $\left(\sigma_{g}\right)$ equal to 3.65 , which means that the sand is uniform size distribution. The $\left(\sigma_{g}\right)$ is outlined as:

$$
\sigma_{g}=\left(\frac{d_{85}}{d_{16}}\right)^{0.5}
$$

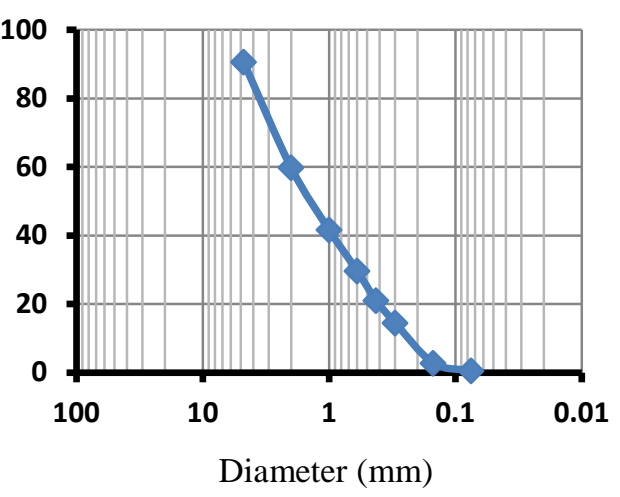

Fig. 4 Grain size distributions.

The sediments used in this investigation square measure well uniform so the results exclude the impact of sediment of non-uniformity so as to remove the reduction of local scour that might be expected to occur in the non-uniform sand as a result of armoring impact.

\section{EQUILIBRIUM TIME}

Equilibrium scour is said to occur when the scour depth does not change adjective with time. Equilibrium can also be know as the asymptotic land of scouring reached as the scouring rate becomes very small or little. For an equilibrium scour condition to be achieved in small scale laboratory experiments of clear water scour, tests must be run for several hours. Ettema [16], defines the time to equilibrium scour as the time at which no more than $1 \mathrm{~mm}$ of gradual scour is realized within a time frame of 4 hours.

To find the restricted (equilibrium) scour time and adopt it in all told test for the aim of eliminating the time effect, totally different velocities of flow were used. The scour wasrecorded at entirely different time intervals using Laser range finder Fig.5, to measure the maximum scour at the bridge piers.

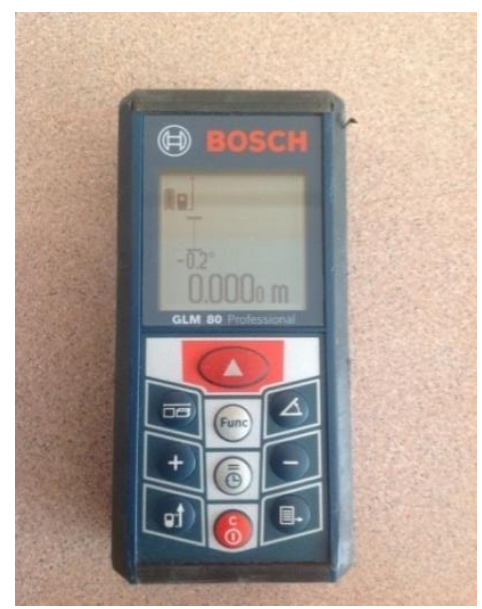

Fig.5 Laser range finder.

When the flow was established the bridge pier models were introduced and bed reading the notes 
were taken at various time intervals, after 5 , $10,15,20,25,30,40,50,60,75,90,75,90,105$, $120,150,180,240,300$, and 360 minutes. Values of scour depth at various test duration as a percentage of final scour depth can be calculated, it is noticed that $97 \%$ of the local scour can be achieved in 180 minutes. Fig. 6 shows the scour hole around the bridge piers. It is seen that scour hole around the piers are symmetric around the longitudinal axis of the bridge piers.

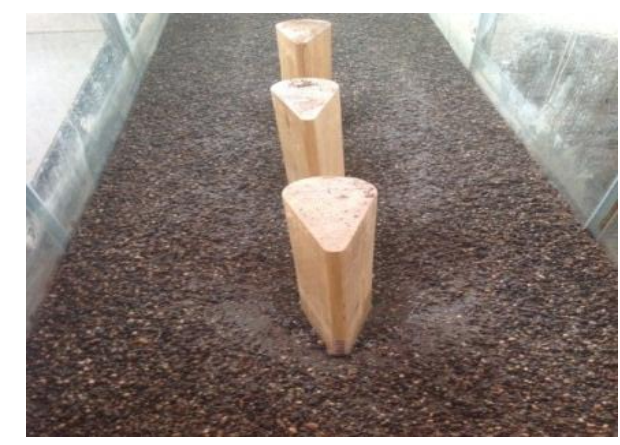

(a) Scour bed around the group of bridge piers $2-10 \mathrm{~cm}$.

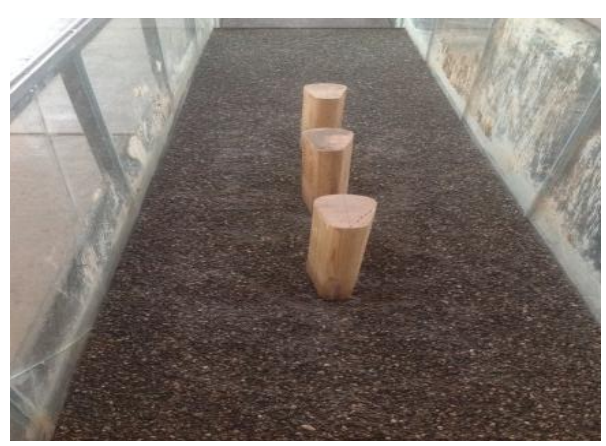

(b) Scour bed around the group of bridge piers 4-10

$\mathrm{cm}$.

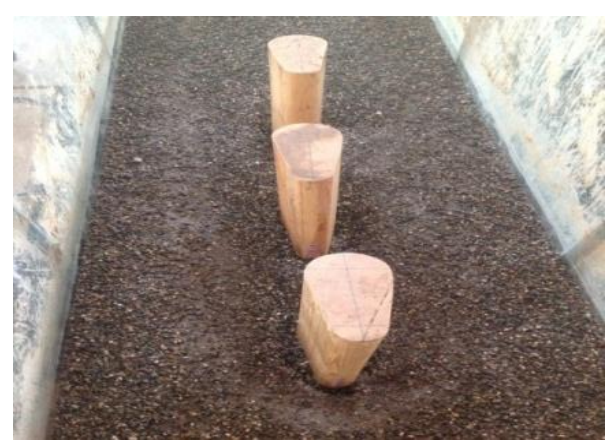

(c) Scour bed around the group of bridge piers $\quad 6-10$ $\mathrm{cm}$.

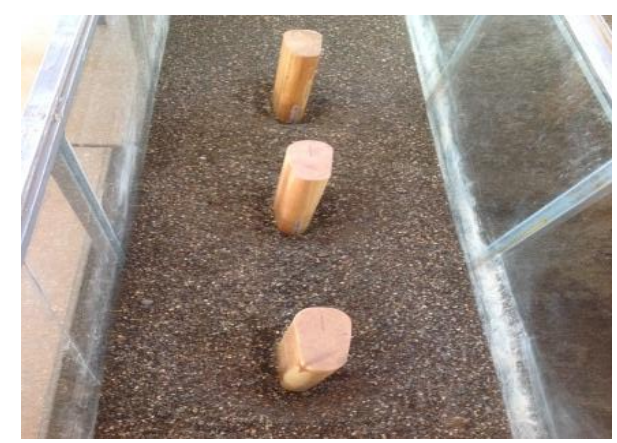

(d) Scour bed around the group of bridge piers 8-10

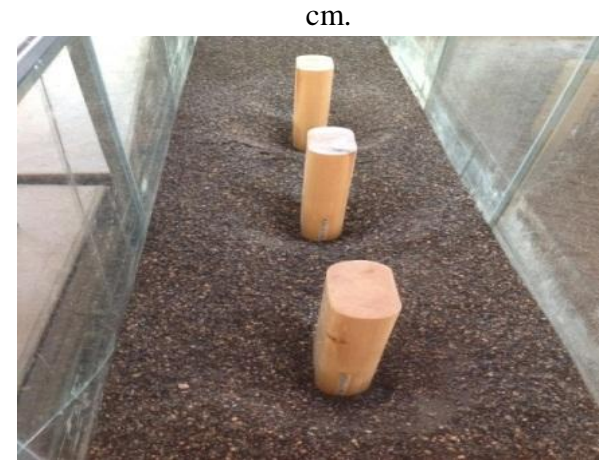

(e) Scour bed around the group of bridge piers 10-10 $\mathrm{cm}$.

Fig.6 Scour bed around the group of bridge piers 2-10 cm, 4-10 cm, 6-10 cm, 8-10 cm and 10$10 \mathrm{~cm}$.

It was noticed that almost change in scour depth occurred at the notes of the bridge piers and after 180 minutes. Fig. 7, Fig. 8 and Fig. 9 shows the rate of the scour plan of bridge piers 2-10, 4-10, 6-10, 8-10 and $10-10 \mathrm{~cm}$, with the time of scour. It is observed that scour formation is very rapid in the first thirty minutes, and these figuresshow the time evolution of scouring plan of bridge piers minimize the rate of scour and then local scour, besides at lower values of discharge the scour decreased and the scour depth increases when the approaching dischargeincrease.Table 2. 
Table. 2 : Depth of scour for group piers 2-10, 4-10, 6-10, 8-10 and 10-10 cm diameters.

\begin{tabular}{|c|c|c|c|c|c|c|c|c|c|c|}
\hline & \multicolumn{3}{|c|}{$d_{\text {s max. }}($ Pier 2-10)mm } & \multicolumn{3}{|c|}{$d_{\text {s max. }}($ Pier4-10)mm } & \multicolumn{3}{|c|}{$d_{\text {s max. }}($ Pier 6-10 $) \mathrm{mm}$} \\
\hline & & Pier 1 & Pier 2 & Pier 3 & Pier 1 & Pier 2 & Pier 3 & Pier 1 & Pier 2 & Pier 3 \\
\hline \multirow{3}{*}{$\begin{array}{l}Q=57 \\
\mathrm{l} / \mathrm{sec}\end{array}$} & $S=50 \mathrm{~cm}$ & 10.0 & 7.3 & 6.2 & 10.7 & 8.2 & 7.0 & 13.5 & 12.1 & 11.0 \\
\hline & $S=30 \mathrm{~cm}$ & 9.0 & 7.0 & 5.2 & 11.0 & 9.2 & 6.5 & 12.6 & 11.3 & 10.6 \\
\hline & $S=20 \mathrm{~cm}$ & 9.4 & 6.8 & 5.0 & 10.6 & 9.4 & 7.0 & 12.0 & 10.9 & 9.4 \\
\hline \multirow{3}{*}{$\begin{array}{l}Q=48 \\
\mathrm{l} / \mathrm{sec}\end{array}$} & $S=50 \mathrm{~cm}$ & 9.2 & 6.5 & 5.5 & 9.8 & 7.2 & 5.3 & 12.2 & 11.3 & 10.1 \\
\hline & $S=30 \mathrm{~cm}$ & 8.0 & 6.0 & 4.7 & 9.2 & 7.0 & 5.2 & 12.0 & 10.8 & 9.3 \\
\hline & $S=20 \mathrm{~cm}$ & 7.8 & 5.6 & 4.3 & 8.8 & 6.6 & 5.0 & 11.6 & 10.5 & 8.3 \\
\hline \multirow{3}{*}{$\begin{array}{l}Q=38 \\
1 / \text { sec }\end{array}$} & $S=50 \mathrm{~cm}$ & 8.0 & 5.4 & 4.8 & 8.2 & 7.3 & 5.0 & 10.5 & 9.8 & 9.2 \\
\hline & $S=30 \mathrm{~cm}$ & 7.0 & 4.8 & 4.2 & 8.0 & 7.0 & 4.3 & 10.5 & 9.2 & 8.0 \\
\hline & $S=20 \mathrm{~cm}$ & 6.5 & 4.6 & 3.8 & 7.7 & 6.7 & 4.2 & 10.2 & 8.8 & 7.8 \\
\hline
\end{tabular}

Table. 2 : (continued)

\begin{tabular}{|c|c|c|c|c|c|c|c|}
\hline & \multicolumn{3}{|c|}{$d_{s \text { max. }}($ Pier 8-10)mm } & \multicolumn{3}{|c|}{$d_{\text {s max. }}($ Pier 10-10 $) \mathrm{mm}$} \\
\hline & & Pier 1 & Pier 2 & Pier 3 & Pier 1 & Pier 2 & Pier 3 \\
\hline \multirow{3}{*}{$\begin{array}{l}\mathrm{Q}=57 \\
\mathrm{l} / \mathrm{sec}\end{array}$} & $S=50 \mathrm{~cm}$ & 14.0 & 13.2 & 12 & 16.0 & 14.9 & 14.2 \\
\hline & $S=30 \mathrm{~cm}$ & 13.5 & 12.8 & 11.5 & 15.0 & 14.3 & 14.0 \\
\hline & $\mathrm{S}=20 \mathrm{~cm}$ & 12.8 & 12.0 & 11.0 & 14.5 & 14.0 & 13.3 \\
\hline \multirow{3}{*}{$\begin{array}{l}\mathrm{Q}=48 \\
\mathrm{l} / \mathrm{sec}\end{array}$} & $S=50 \mathrm{~cm}$ & 13.2 & 12.2 & 11.5 & 14.2 & 13.2 & 12.7 \\
\hline & $\mathrm{S}=30 \mathrm{~cm}$ & 13.0 & 11.4 & 10.8 & 13.5 & 12.2 & 12.0 \\
\hline & $S=20 \mathrm{~cm}$ & 12.4 & 11.0 & 10.0 & 13.2 & 11.8 & 11.0 \\
\hline \multirow{3}{*}{$\begin{array}{l}\mathrm{Q}=38 \\
\mathrm{l} / \mathrm{sec}\end{array}$} & $S=50 \mathrm{~cm}$ & 13.0 & 11.0 & 10.5 & 13.5 & 12.8 & 11.8 \\
\hline & $S=30 \mathrm{~cm}$ & 12.0 & 10.5 & 10.0 & 12.4 & 11.2 & 11.0 \\
\hline & $S=20 \mathrm{~cm}$ & 11.8 & 10.2 & 9.8 & 11.6 & 10.7 & 10.5 \\
\hline
\end{tabular}

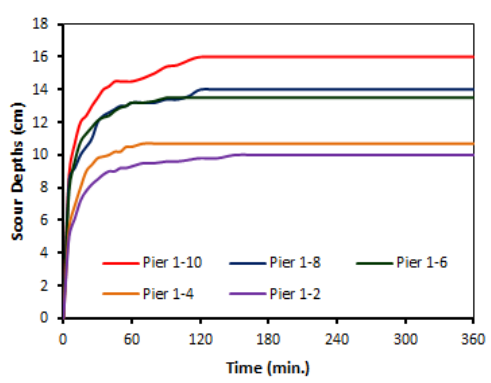

Pier $1, \mathrm{Q}=57 \mathrm{l} / \mathrm{s}$ and $\mathrm{S}=50 \mathrm{~cm}$

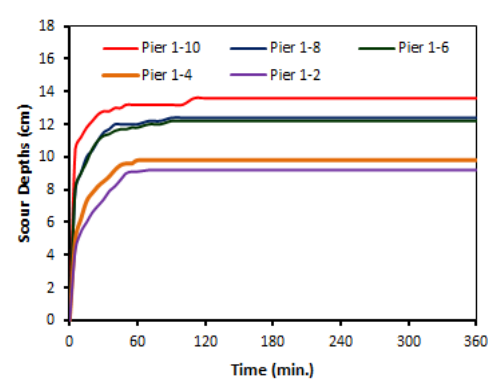

Pier $1, \mathrm{Q}=48 \mathrm{l} / \mathrm{s}$ and $\mathrm{S}=50 \mathrm{~cm}$

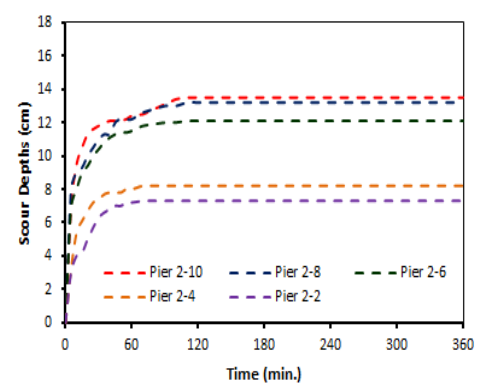

Pier $2, \mathrm{Q}=57 \mathrm{l} / \mathrm{s}$ and $\mathrm{S}=50 \mathrm{~cm}$

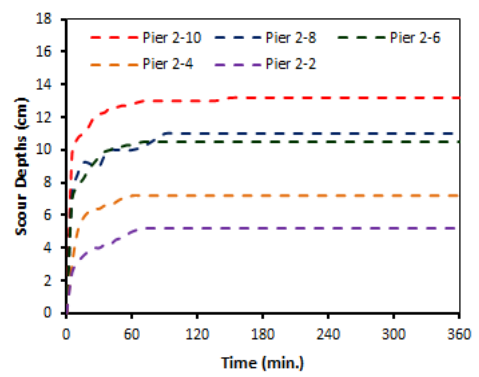

Pier 2, $Q=48 \mathrm{l} / \mathrm{s}$ and $\mathrm{S}=50 \mathrm{~cm}$

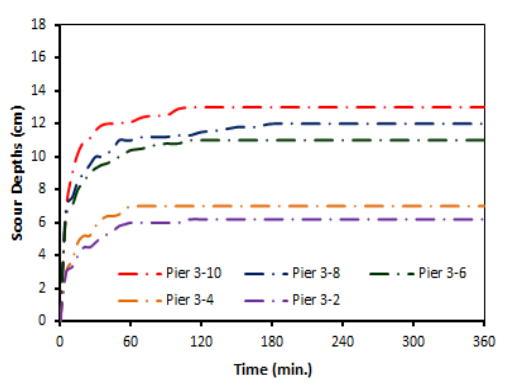

Pier $3, Q=57 \mathrm{l} / \mathrm{s}$ and $\mathrm{S}=50 \mathrm{~cm}$

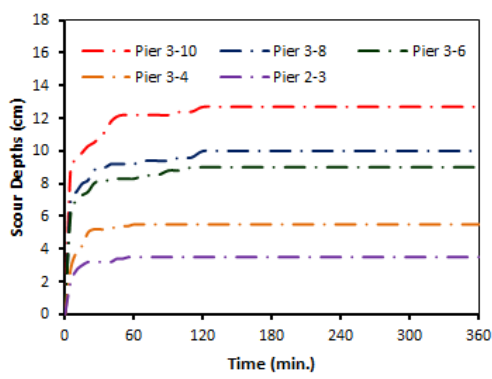

Pier 3, $Q=48 \mathrm{l} / \mathrm{s}$ and $\mathrm{S}=50 \mathrm{~cm}$ 


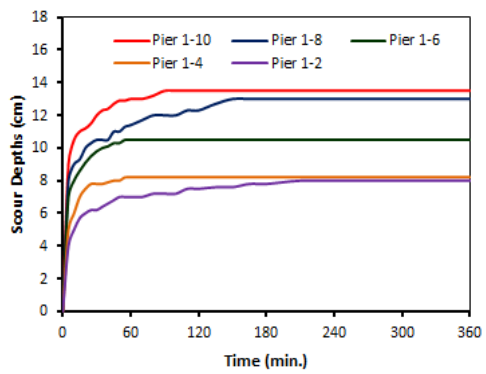

Pier $1, \mathrm{Q}=38 \mathrm{l} / \mathrm{s}$ and $\mathrm{S}=50 \mathrm{~cm}$

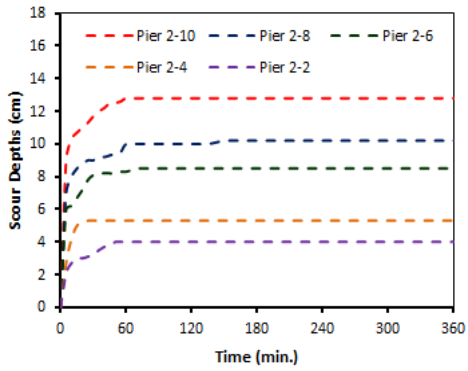

Pier $2, \mathrm{Q}=38 \mathrm{l} / \mathrm{s}$ and $\mathrm{S}=50 \mathrm{~cm}$

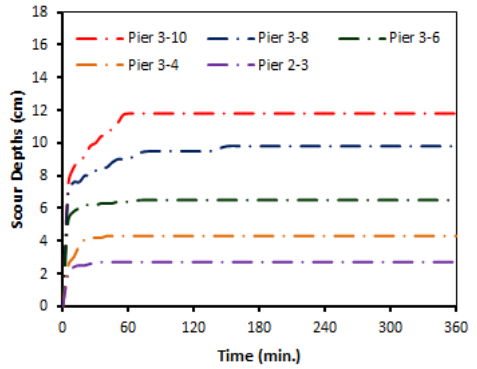

Pier $3, \mathrm{Q}=38 \mathrm{l} / \mathrm{s}$ and $\mathrm{S}=50 \mathrm{~cm}$

Fig.7 Time evolution in scour depths for bridge piers $2-10,4-10,6-10,8-10$ and $10-10 \mathrm{~cm}, \mathrm{~S}=50 \mathrm{~cm}$., $\mathrm{Q}=$ $57,48,38 \mathrm{l} / \mathrm{sec}$.

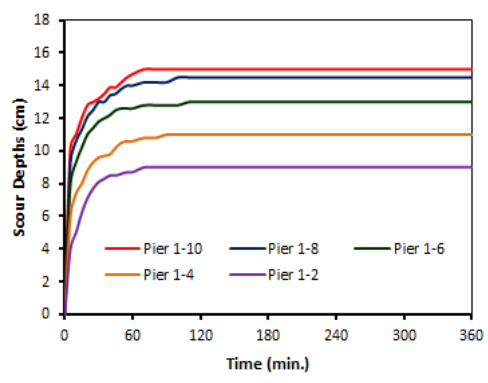

Pier $1, Q=571 / \mathrm{s}$ and $\mathrm{S}=30 \mathrm{~cm}$

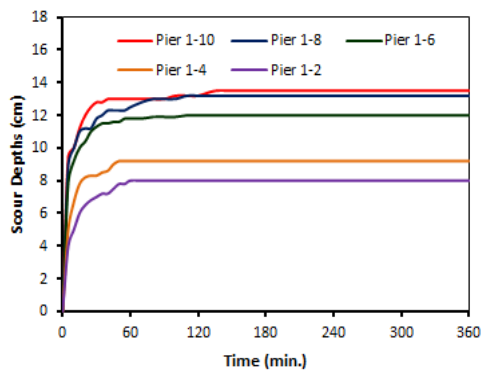

Pier $1, \mathrm{Q}=48 \mathrm{l} / \mathrm{s}$ and $\mathrm{S}=30 \mathrm{~cm}$

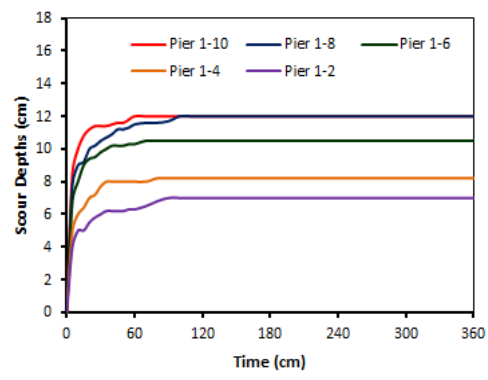

Pier $1, \mathrm{Q}=38 \mathrm{l} / \mathrm{s}$ and $\mathrm{S}=30 \mathrm{~cm}$

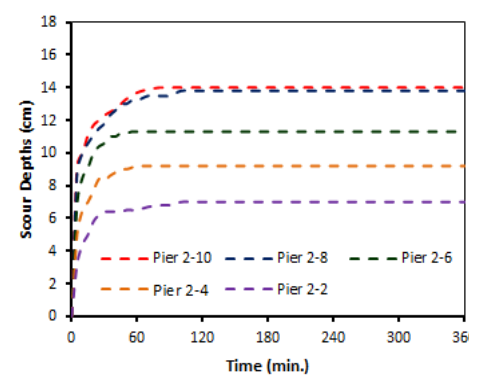

Pier $2, \mathrm{Q}=57 \mathrm{l} / \mathrm{s}$ and $\mathrm{S}=30 \mathrm{~cm}$

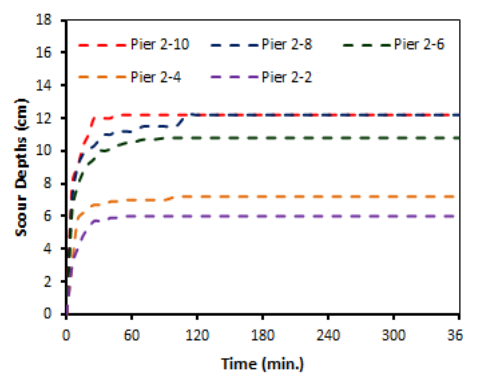

Pier $2, Q=48 \mathrm{l} / \mathrm{s}$ and $\mathrm{S}=30 \mathrm{~cm}$

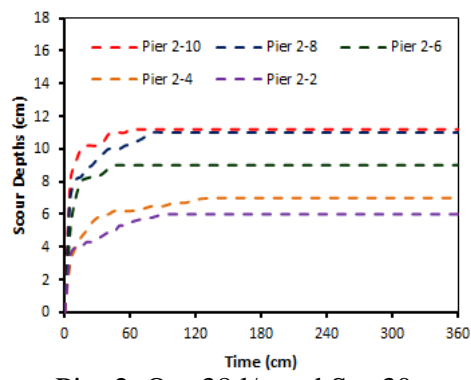

Pier $2, \mathrm{Q}=38 \mathrm{l} / \mathrm{s}$ and $\mathrm{S}=30 \mathrm{~cm}$

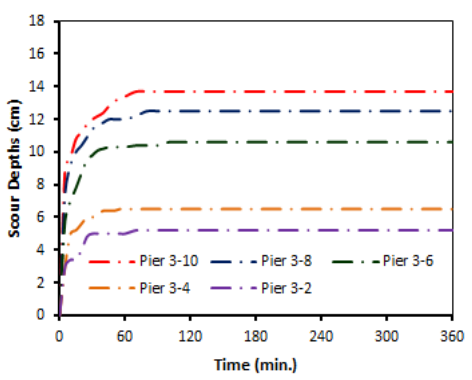

Pier $3, Q=571 / \mathrm{s}$ and $\mathrm{S}=30 \mathrm{~cm}$

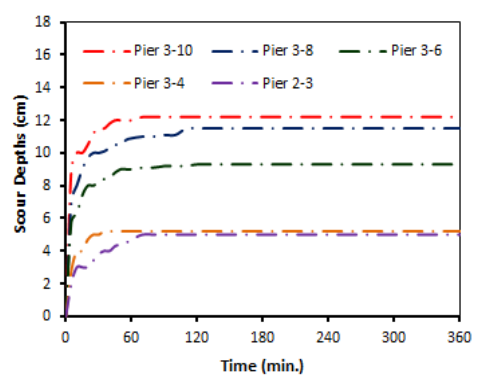

Pier $3, Q=481 / \mathrm{s}$ and $\mathrm{S}=30 \mathrm{~cm}$

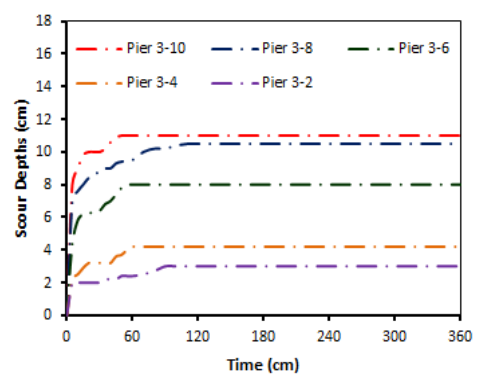

Pier $3, Q=38 \mathrm{l} / \mathrm{s}$ and $\mathrm{S}=30 \mathrm{~cm}$

Fig.8 Time evolution in scour depths for bridge piers $2-10,4-10,6-10,8-10$ and $10-10 \mathrm{~cm}, \mathrm{~S}=30 \mathrm{~cm} ., \mathrm{Q}=$ $57,48,38 \mathrm{l} / \mathrm{sec}$. 


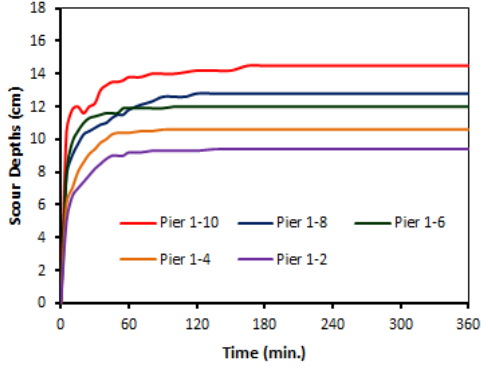

Pier $1, \mathrm{Q}=57 \mathrm{l} / \mathrm{s}$ and $\mathrm{S}=20 \mathrm{~cm}$

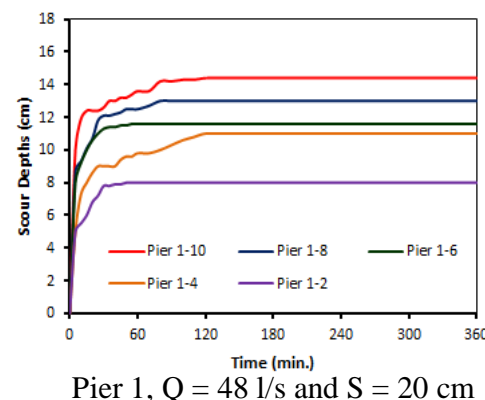

Pier $1, \mathrm{Q}=48 \mathrm{l} / \mathrm{s}$ and $\mathrm{S}=20 \mathrm{~cm}$

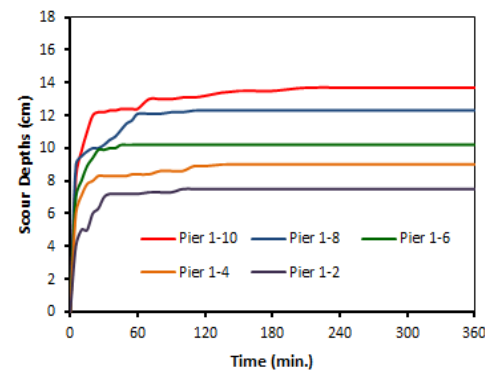

Pier $1, \mathrm{Q}=38 \mathrm{l} / \mathrm{s}$ and $\mathrm{S}=20 \mathrm{~cm}$

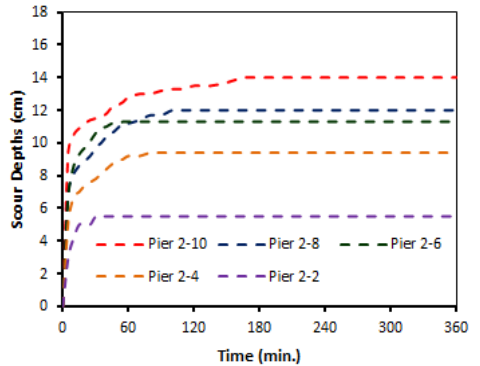

Pier $2, \mathrm{Q}=57 \mathrm{l} / \mathrm{s}$ and $\mathrm{S}=20 \mathrm{~cm}$

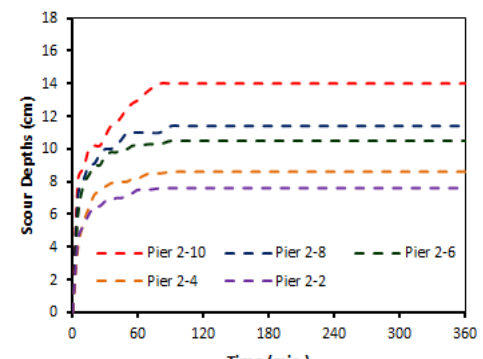

Pier $2, Q \stackrel{\text { Time (min.) }}{=} 48 \mathrm{l} / \mathrm{s}$ and $\mathrm{S}=20 \mathrm{~cm}$

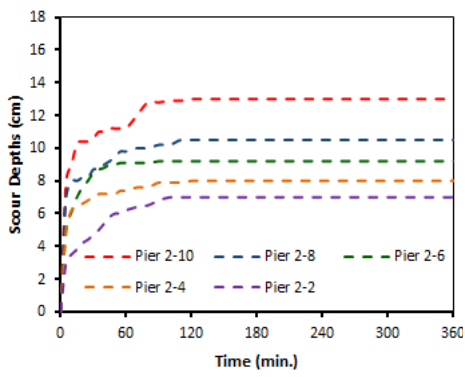

Pier $2, \mathrm{Q}=38 \mathrm{l} / \mathrm{s}$ and $\mathrm{S}=20 \mathrm{~cm}$

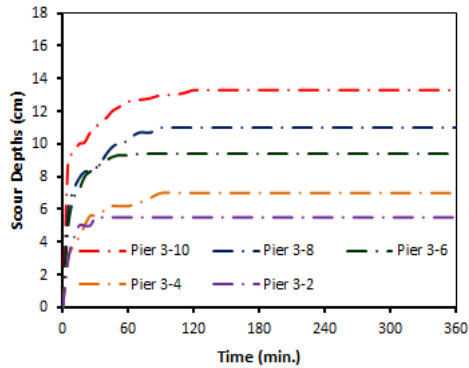

Pier $3, Q=571 / \mathrm{s}$ and $S=20 \mathrm{~cm}$

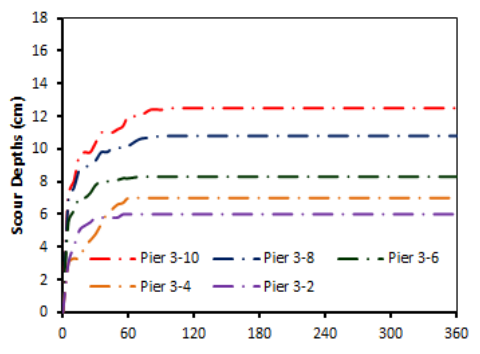

Pier 3, $\mathrm{Q}=48 \mathrm{Time}(\mathrm{min}$.$) and \mathrm{S}=20 \mathrm{~cm}$

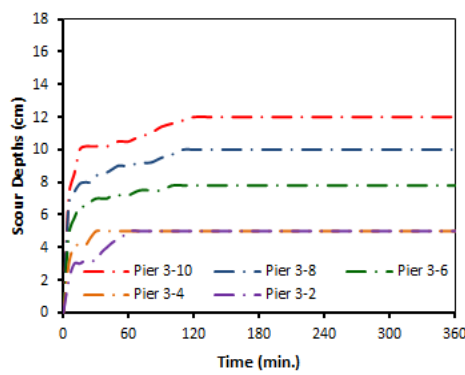

Pier $3, Q=381 / \mathrm{s}$ and $\mathrm{S}=20 \mathrm{~cm}$

Fig.9 Time evolution in scour depths for bridge piers $2-10,4-10,6-10,8-10$ and $10-10 \mathrm{~cm}, \mathrm{~S}=20 \mathrm{~cm}$., $\mathrm{Q}=57,48,38 \mathrm{l} / \mathrm{sec}$.

\section{SPACINGBETWEEN BRIDGE PIERS}

The scour depth at the group bridge pier is different from that around a single bridge pier depending on the bridge pier spacing, smaller bridge pier spacing causes a substantial interference between the bridge piers [17]. The scour depthdeferent with spacing and the scour depth development at the upstream was higher compared to the downstream before it reaches the equilibrium state. The spacing between the bridge piers has a direct impact on the scouring process. That is the scour depth decreases with increasing the spacing between the bridge piers. Used three different distances between five group bridge piers $\mathrm{S}=20,30,50 \mathrm{~cm}$ in order to deduce the effect of space between bridge piers on the scour depth. A set of experiments is conducted for evaluating the relationship between the spacing and the scour depth. For elucidation on the influence of space between the bridge piers, the bed elevation sections are prepared and presented in Fig. 10, Fig. 11, Fig. 12. It can be seen from these figures that the scouring process is greater when the spacing increases, while the other influencing parameters (flow depth and velocity of flow) are kept constant.

Through practical experiments has been observed the maximum scour depth and scour hole they are about the first bridge pier and start decreasing around second and third piers for all bridge pier diameters and all spacing for used in this study. 

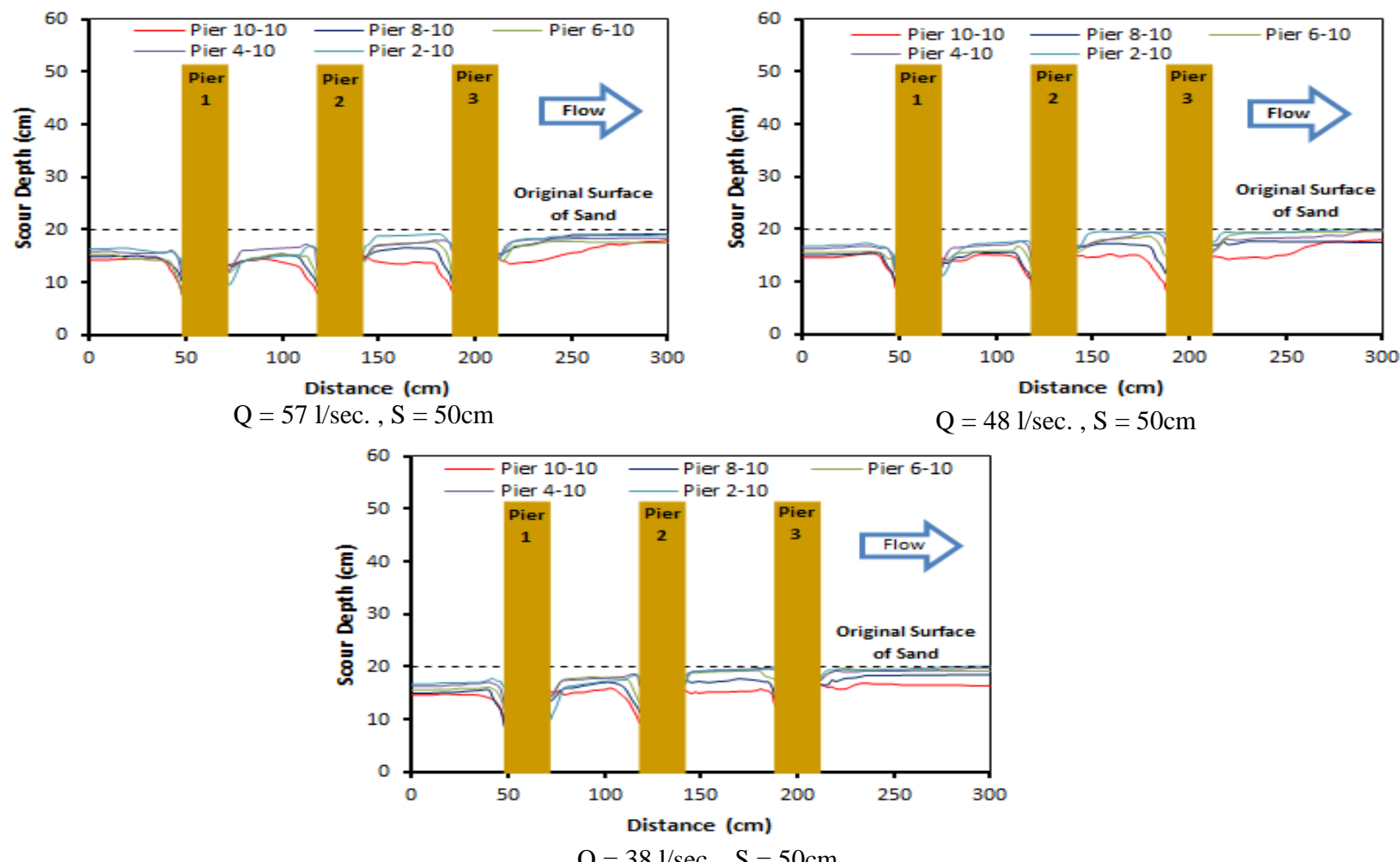

$\mathrm{Q}=38 \mathrm{1} / \mathrm{sec} ., \mathrm{S}=50 \mathrm{~cm}$

Fig.10 Longitudinal profile of bed for bridge piers $2-10,4-10,6-10,8-10$ and $10-10 \mathrm{~cm}$, for $\mathrm{Q}=57,48$ and $38 \mathrm{l} / \mathrm{sec}$. and $\mathrm{S}=50 \mathrm{~cm}$.
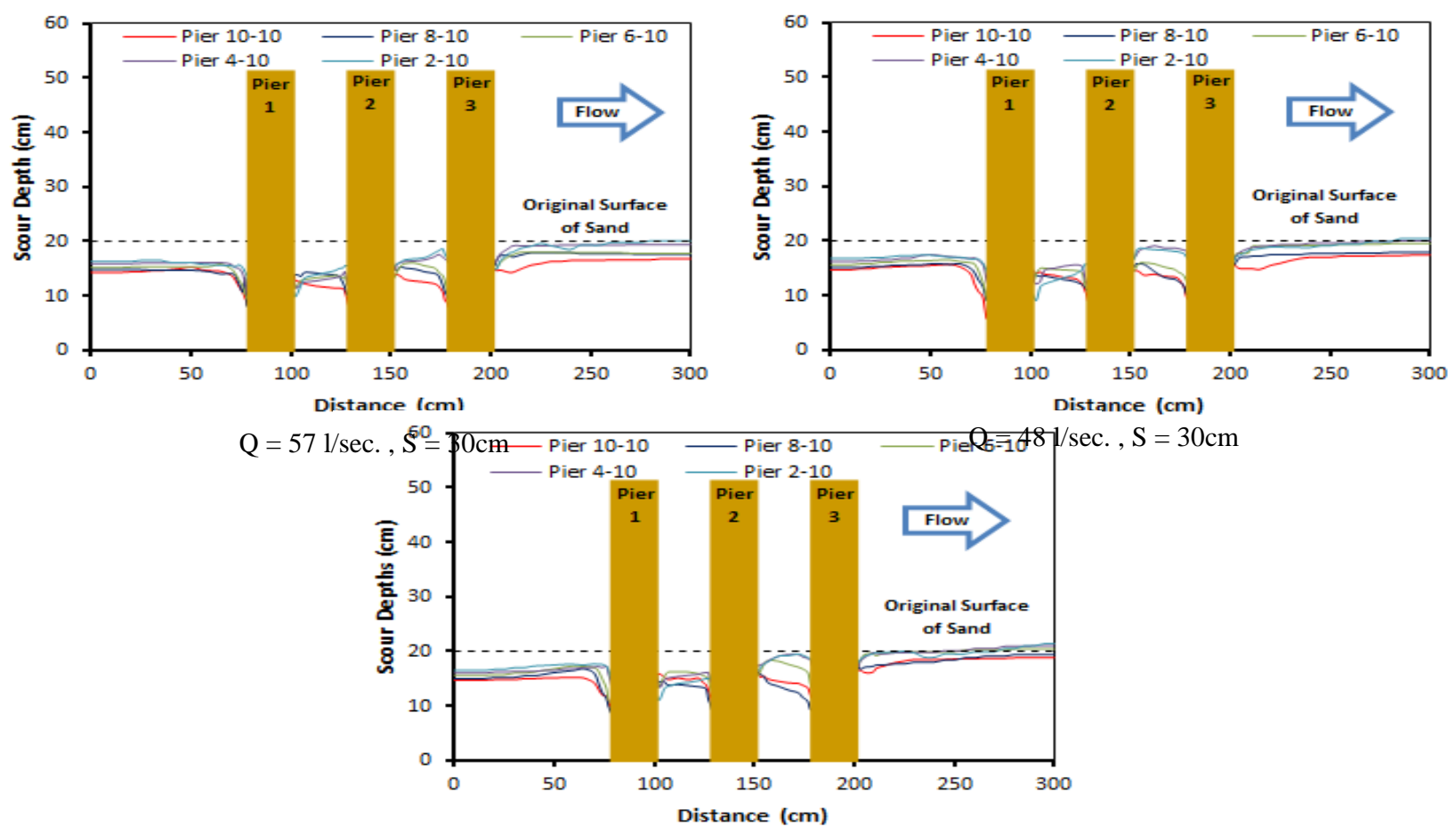

$\mathrm{Q}=38 \mathrm{l} / \mathrm{sec} ., \mathrm{S}=30 \mathrm{~cm}$ 
Fig. 11 Longitudinal profile of bed for bridge piers 2-10, 4-10, 6-10, 8-10 and 10-10 cm, for Q = 57, 48 and $38 \mathrm{l} / \mathrm{sec}$. and $\mathrm{S}=30 \mathrm{~cm}$.
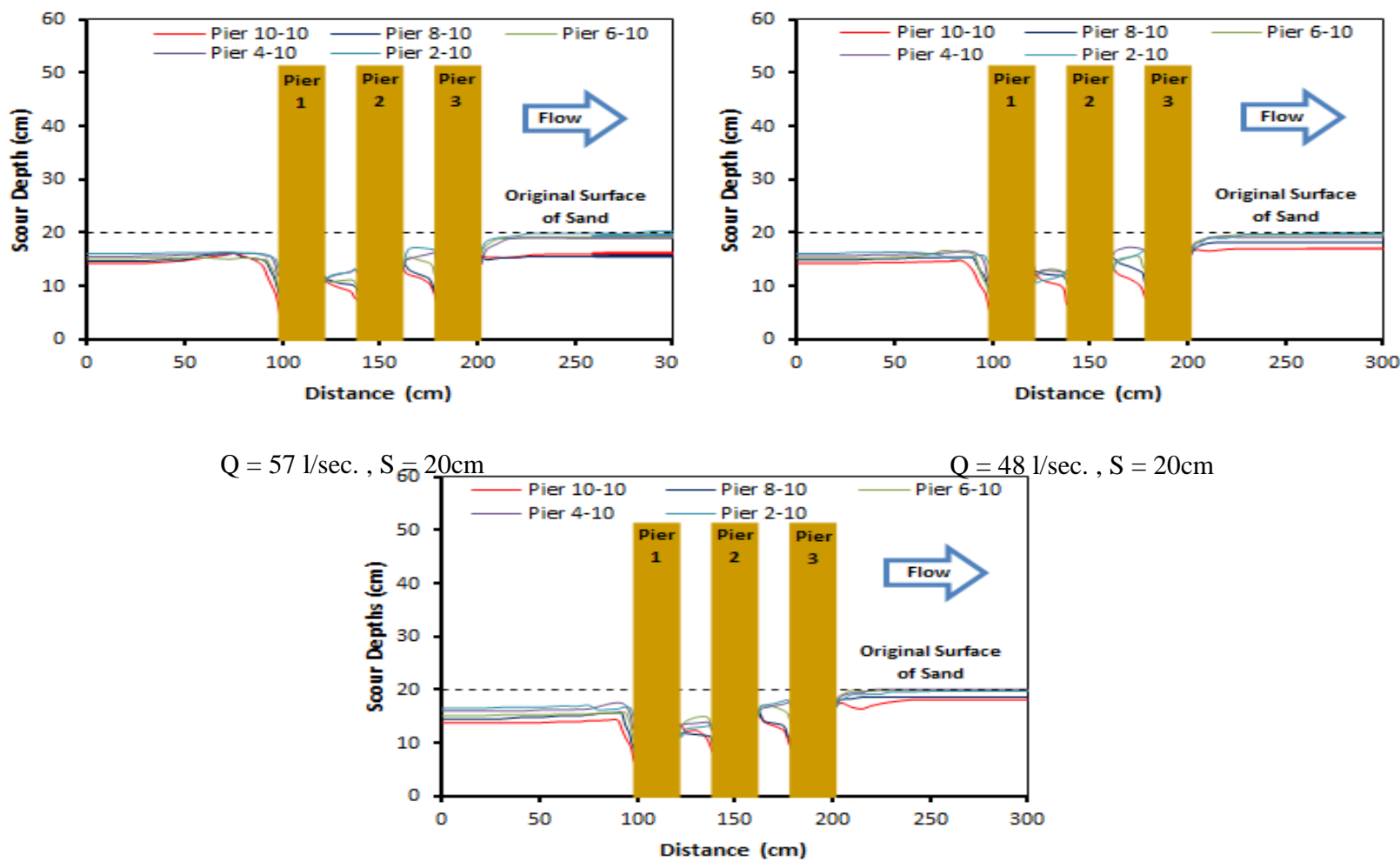

$$
\mathrm{Q}=38 \mathrm{l} / \mathrm{sec} ., \mathrm{S}=20 \mathrm{~cm}
$$

Fig. 12 Longitudinal profile of bed for bridge piers $2-10,4-10,6-10,8-10$ and $10-10 \mathrm{~cm}$, for $\mathrm{Q}=57,48$ and $38 \mathrm{l} / \mathrm{sec}$. and $\mathrm{S}=20 \mathrm{~cm}$.

\section{DEVELOPMENTOF NEW FORMULA}

Local scour at bridge piers is a function of many variables. Scour depth at bridge piers as in Fig. 13, depends on variables describe the fluid, flow, bed sediment and bridge piers.Hence, the following functional relationship can characterizing the scour depth.

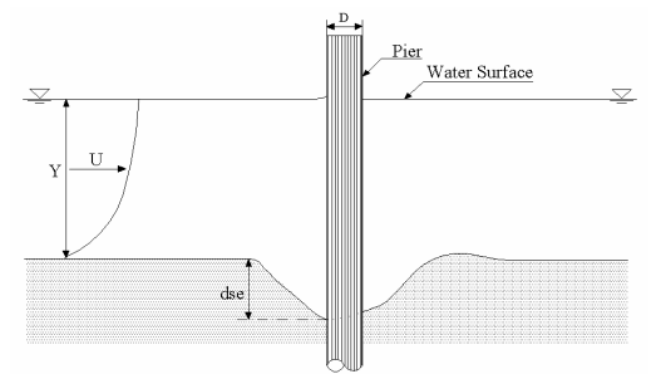

Fig.13 Flow and local scour around bridge pier.

$d_{s}=f\left(h, V, V_{c}, \rho, g, S, d_{50}, \mu, D\right)$

In which $\mathrm{h}$ is the flow depth, $\mathrm{V}$ is the flow velocity, $V_{c}$ is the critical velocity, $\rho$ is the density of fluid, $g$ is the gravitational acceleration, $\mathrm{S}$ is the spacing between bridge piers, $d_{50}$ is the median particle grain size, $\mu$ is the dynamic viscosity of water and D is the upstream diameter of bridge pier.

The equation can be written from Buckingham $\pi$ - theorem.

$f_{1}\left(d_{s}, h, V, V_{c}, \rho, g, S, d_{50}, \mu, D\right)=0$

After the simplification of the equations above and eliminating the parameters with constant and negligible values and applying the assumption.

$\mathrm{f}_{2}\left(\frac{\mathrm{d}_{\mathrm{s}}}{\mathrm{h}}, \frac{\mathrm{V}_{\mathrm{c}}}{\mathrm{V}}, \mathrm{Fr}, \frac{\mathrm{s}}{\mathrm{h}}, \frac{\mathrm{D}}{\mathrm{h}}\right)=0$

In which Fr is the Froud's Number, the functional relationship which describes the scour depth normalize with flow depth may be written as:

$\frac{d_{s}}{h}=f_{3}\left(\frac{V_{c}}{V}, F r, \frac{s}{h}, \frac{D}{h}\right)$

The computer package SPSS Statistics 20 is used to make analysis the experimental data for three groups of bridge piers 2-10, 4-10, 6- 
$10,8-10$ and $10-10 \mathrm{~cm}$ to find the equation through a non-linear regression analysis.

$$
\begin{aligned}
& \frac{\mathrm{d}_{\mathrm{s}}}{\mathrm{h}}=0.368\left(\frac{\mathrm{V}_{\mathrm{c}}}{\mathrm{V}}\right)^{1.092}(\mathrm{Fr})^{-1.281}\left(\frac{\mathrm{S}}{\mathrm{h}}\right)^{0.169} \\
& \left(\frac{\mathrm{D}_{1}}{\mathrm{~h}}\right)^{0.490} \text { (6) }
\end{aligned}
$$

The coefficient of definition, $\mathrm{R}^{2}$ for this equation is 0.809 .

The relation between experimentally observed values of $\frac{d_{s}}{h}$ and values predicted by equation (6) shown in Fig. 14.Fig.14 Relation between observed and predicted $\frac{\mathrm{d}_{\mathrm{s}}}{\mathrm{h}}$ values.

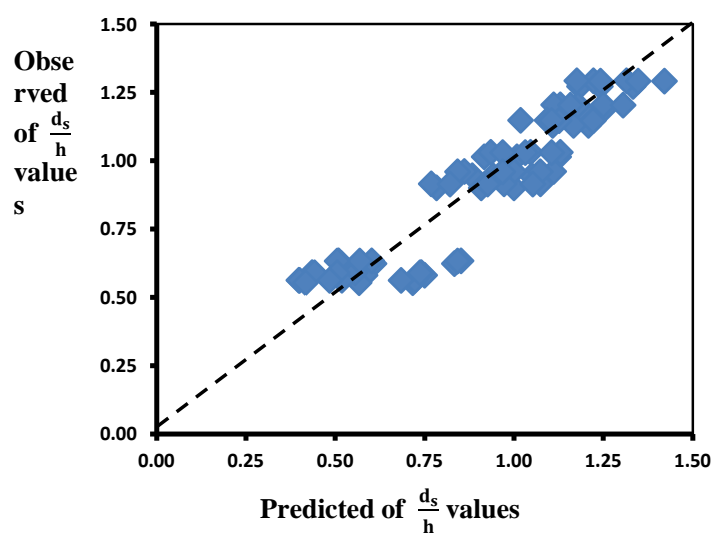

Fig.14 Relation between observed and predicted $\frac{\mathrm{d}_{\mathrm{s}}}{\mathrm{h}}$ values.

\section{CONCLUSIONS}

The problem of local scour around the bridge piers has been studied experimentally. Under the definition (subcritical flow, clear water condition and adopting uniform cohesionless sand as bed material) imposed on this study, the following conclusions can be drawn.

1. The maximum scour depth was observed at the first upstream bridge piers for all different diameters and spacing.

2. For a constant upstream diameter of group bridge piers, the scour depth increases due to increasing the flow depth and flow velocity.

3. The depth of scour occurs at the head of the first bridge piers because of its objection to the flow.

4. As the number of bridge piers increase, the depth of scour decreases.
5. The increase of bridge pier diameter increased the scour depth.

6. The scour depth increased for bridge piers by increasing the spacing between them.

7. The new formula for the maximum depth of scour Eq. (6), is developed by using the dimensional analysis techniques. This formulais restricted to the laboratory. The scour depth is represented as a function of Froude Number, flow velocity, critical flow velocity, and spacing between the bridge piers.

\section{REFERENCE}

[1] Charise, R.: Erosion of sand beds around spur-dikes. Journal of Hydraulic Division. ASCE, HY5, May, 860-862 (1973)

[2] Raudkivi, A.; Ettema, R.: Effect of sediment gradation on clear water scour and measurement of scour depth. Journal of Hydraulic Division. ASCE, Vol.103, HY10, 1209-1213 (1977)

[3] Umesh, C.; Ashish, K.: Temporal variation of scour around circular compound piers. Journal of Hydraulic Engineering. ASCE, 135(11), 945-957 (2012)

[4] Koustuv, D.; Susanta, Ch.,: Local scour around non-circular piers in clay-sand mixed cohesive sediment beds. Journal of Engineering Geology. 151, 1-14 (2012)

[5] Heidarpour, M.; Khodarahim, Z.: Control and reduction of local scour at bridge pier groups usingslot. Proceeding IAHIR congress. Thessaloniki, Greece, August, 24-29 (2003)

[6] Zarrati, A.; Gholami, H.: Application of collar to control scouring around rectangular bridge piers. Journal of Hydraulic Research. IAHR, vol. 1, 97-103 (2004)

[7] Fenocchi, A.; Natale, L.: Using numerical and physical modeling to evaluate total scour at bridge piers. Journal of Hydraulic Engineering , 142(3), (2016)

[8] Dey, S.: Time variation of scour in the vicinity of circular piers. Water and maritime engineering journal. Proceeding of the institution of civil engineers. Vol.136, No.2, 67-75 (1999)

[9] Ettema, R.; Raudkivi, A.: Clear water scour at cylindrical piers. Journal of Hydraulic Engineering. ASCE, vol.109, No.3, 338-350 (1983)

[10] Lagasse, P.; Richardson, E.: Compendium of stream stability and bridge scour paper. Journal of Hydraulic 
a. Engineering. ASCE, Vol. 127, No. 7, 531-533 (2001)

[11] Nandana V.; and et al.: Clear water scour around bridge piers group. Journal of Hydraulic Engineering. ASCE, Vol. 120, 1309-1318 (1994)

[12] K. Debnath; and et al.: Turbulence statistics of flow over scoured cohesive sediment bed around circular cylinder. Advances in Water Resources. Vol.41, 18-28 (2012)

[13] Shatirah, A.; and et al.: Local scour around complex pier groups and combined piles at semi-integral bridge. Journal of Hyrol. Hydromech. Vol. 62, 108-116 (2014)

[14] Adnan, I; and et al.: Effect of bridge pier position on scour reduction according to flow direction. Arabian Journal for
Science and Engineering. 40: 1579-1590 (2015)

[15] Melville, B.W.; Chiew, Y.M.: Time scale for local scour at bridge piers. Journal of Hydraulic Engineering. ASCE, 125(1), 59-65 (1999)

[16] Ettem, R.: Scour at bridge piers. PhD., Thesis, Auckland University, Auckland, New Zealand (1980)

[17] B. Ataie-Ashtiani; and et al.: Experimental investigation of clear-water local scour of compound piers. Journal of Hydraulic Engineering. ASCE, June, 343351 (2010) 


\section{دراسة النحر حول دعامـات الجسور باشكال مختلفة \\ خليل ابراهيم عثمان مصطفى كونال

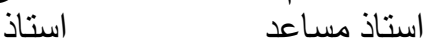 \\ تحسين علي جلميران}

الملخص

تم في هذه البحث اجر اء دراسة مختبرية لقياس عمق النحر الموضعي (ds) حول عدة مجاميع من دعامات الجسور. لهذه الغاية تم تصنيع وفحص

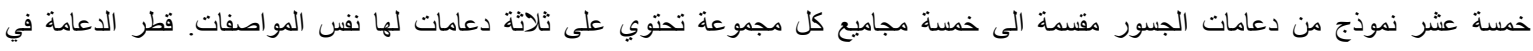
مقدمة(D) تم تغييره (2,4,6,8,10) سم, بينما قطر الدعامة في المؤخرة (D, (D)بقي ثابتا لجميع النماذج المستخدمة في الدراسة (10) سم و المسافة بين الدعامات (S) تم تغيير هائلاث مر ات ( 20, 30, 50 ) سم على التو الي لكل مجموعة.

تم دراسة خصائص الجريان وقطر مقدمة الدعامة والمسافة بين الدعامات وحجم حبييات تربة القعر مع اكبر عمق للنحر حول هذه العامات وتم التوصل من خلال النتائج العملية ان عمق النحر يزداد بزيادة قطر مقدمة الدعامة ويقل كلما قلت المسافة بين الدعامات ومن خلال التحليل البعدي واستخدام

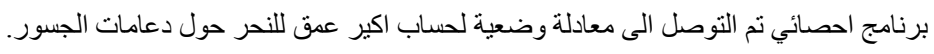
الكلمات الدالة

مجمو عة دعامات الجسور, النحر لاعامات مختلفة الاشكال, مسافات مختلفة بين الدعامات, اقطار مختلفة لمقدة الدعامات 